\title{
BIOLOGICAL EVALUATION AND PHYTOCHEMICAL PROFILING OF SOME LICHEN SPECIES
}

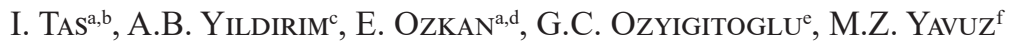 \\ and A.U. TURKER ${ }^{\text {a* }}$ \\ ${ }^{a}$ Department of Biology, Faculty of Arts and Sciences, Bolu Abant Izzet Baysal University, 14280, Bolu. Turkey \\ ${ }^{b}$ Korean Lichen Research Institute, Sunchon National University, Sunchon, Republic of Korea \\ ${ }^{c}$ Department of Field Crops, Faculty of Agriculture and Natural Sciences, Bolu Abant Izzet Baysal University, \\ Bolu. Turkey \\ ${ }^{\mathrm{d} D e p a r t m e n t ~ o f ~ N u c l e a r ~ M e d i c i n e, ~ C h o n n a m ~ N a t i o n a l ~ U n i v e r s i t y ~ M e d i c a l ~ S c h o o l ~ a n d ~ H w a s u n ~ H o s p i t a l, ~ G w a n g j u . ~}$ \\ Republic of Korea \\ ${ }^{\mathrm{e}}$ Department of Biology, Faculty of Arts and Sciences, Marmara University, Istanbul. Turkey \\ ${ }^{f}$ Department of Pharmacology, Faculty of Medicine, Bolu Abant Izzet Baysal University, Bolu. Turkey
}

(Received: 6 March 2019; accepted: 6 May 2019)

\begin{abstract}
Lichens are a symbiotic relationship between a fungus and a photosynthetic partner. Chemical characterization and bioactive potentials (antiproliferative, antioxidant, and antibacterial) of five lichen species (Evernia prunastri, Platismatia glauca, Pseudevernia furfuracea, Ramalina fastigiata, and Ramalina farinacea) were assessed. Five lichen metabolites (usnic acid, atranorin, stictic acid, evernic acid, and fumarprotocetraric acid) were analyzed by HPLC-DAD. E. prunastri was noteworthy evernic acid source. Antiproliferative activity was evaluated using human breast adenocarcinoma (MCF-7) and human hepatocellular carcinoma (HepG2/C3A) cell lines. The strongest activity was observed for $P$. glauca against $\mathrm{HepG} 2 / \mathrm{C} 3 \mathrm{~A}$, while the only lichen species that induced cytotoxicity against MCF-7 cell line was $P$. furfuracea. The highest antioxidant activity was also obtained with $P$. furfuracea. E. prunastri and R. farinaceae had the highest phenolic and flavonoid contents, respectively. Antibacterial activities of the extracts were determined against ten pathogenic bacteria. The most effective antibacterial agent was methanol extract of $R$. fastigiata. Our findings have revealed the pharmaceutical potentials of tested lichen species.
\end{abstract}

Keywords: antibacterial, antioxidant, antiproliferative, chemical profile, HPLC, lichen

It is estimated that about $18000-25000$ lichen species are colonized in the world (SIPMAN \& Aptroot, 2001; Chapman, 2009). They have been used traditionally as medicine by Chinese people and Native Americans for hundreds of years. They are also used as food source, natural dyes, as well as in the alcohol and perfume industries (KosAnIC et al., 2013).

More than a thousand different secondary metabolites have been reported for lichen species and their mycobionts (MOLNáR \& FARKAS, 2010). Previous studies indicate that lichen secondary metabolites exert a broad range of biological activities that comprise antibiotic, antiviral, antimycobacterial, antiinflammatory, analgesic, enzyme inhibitory, antipyretic, and cytotoxic effects (KosAnic et al., 2013; KorKmaz et al., 2018). While the potential of the numerous lichen compounds was elucidated, many promising candidates still need to be investigated.

The present study aims to assess the antioxidant, antibacterial, and antiproliferative potentials of five lichen species and to elucidate their chemical contents by HPLC-DAD as possible therapeutic agents.

\footnotetext{
* To whom correspondence should be addressed.

Phone: +90 37425412 38; fax: +90 37425346 42; e-mail: turker_a@ibu.edu.tr
} 


\section{Materials and methods}

\subsection{Lichen material and extraction}

Five different lichen species [Evernia prunastri (L.) Ach., Platismatia glauca (L.) W.L.Culb. \& C.F.Culb., and Pseudevernia furfuracea (L.) Zopf. from Parmeliaceae; Ramalina fastigiata (Pers.) Ach. and Ramalina farinacea (L.) Ach. from Ramalinaceae families] were collected from several provinces (Lake Abant province, Aladağlar province, and Lake Seben province) of Bolu, Turkey between 2014-2015. Extraction procedures were performed according to the method described by TAS and co-workers (2017).

\subsection{High-performance liquid chromatography (HPLC-DAD) analysis}

HPLC-DAD analysis was conducted according to the method described by KOSANIC and coworkers (2014).

\subsection{Antiproliferative activity}

Antiproliferative activity of acetone extracts of tested lichens against human breast adenocarcinoma (MCF-7) and human hepatocellular carcinoma (HepG2/C3A) cell lines were determined by using MTT (3-(4,5-dimethylthiazol-2-yl)-2,5-diphenyl-tetrazolium bromide) colorimetric assay (MOSMANN, 1983) according to the procedure described by TAS and co-workers (2017).

\subsection{Free radical scavenging activity}

Free radical scavenging activity of methanol extracts of lichen species was evaluated by using 2,2-diphenyl-1-picrylhydrazil (DPPH•, Sigma $\left.{ }^{\circledR}\right)$ radical photometric assay according to BLoIs (1958)'s method modified by TAS and co-workers (2017).

\subsection{Determination of total phenolic and flavonoid contents}

Phenolic and flavonoid contents in methanol and acetone extracts of lichens were determined by using the Folin-Ciocalteu (SLINKARD \& SingLETON, 1977) and aluminium chloride $\left(\mathrm{AlCl}_{3}\right)$ colorimetric assays (ZHISHEN et al., 1999), respectively, with some modifications described by TAS and co-workers (2017).

\subsection{Antibacterial bioassay}

Antibacterial effect of lichen extracts was investigated against ten pathogenic bacteria by using disc diffusion method (ANDREWs, 2009) with some modifications described by TAS and co-workers (2017).

\subsection{Statistical analysis}

Data analysis was conducted by analysis of variance (ANOVA) and Duncan's multiple range tests using SPSS vers. 15 (SPSS Inc, Chicago, IL, USA). 


\section{Results and discussion}

Chemical constituents of tested lichen species and extraction yields are shown in Table 1. HPLC-DAD analysis showed that acetone was more efficient solvent for obtaining lichen metabolites (Table 1). The chromatogram of the standards and each analyzed lichen species are demonstrated in Figures 1 and 2, respectively.

Table 1. Tested lichen species and quantitative analysis of extracts by HPLC-DAD

\begin{tabular}{lccccccc}
\hline Lichen species & Extract & $\begin{array}{l}\text { Yield } \\
\text { (\%) }\end{array}$ & & \multicolumn{5}{c}{ Standard compounds $\left(\mathrm{mg} \mathrm{g}^{-1}\right.$ dry extract) } \\
\cline { 3 - 8 } & & & Atranorin & Evernic acid & Usnic acid & Stictic acid & $\begin{array}{c}\text { Fumarprotoce- } \\
\text { traric acid }\end{array}$ \\
\hline E. prunastri & AE & 7 & $102.27 \pm 0.17$ & $258.81 \pm 0.43$ & $22.20 \pm 1.10$ & - & - \\
& ME & 8.6 & $10.09 \pm 0.07$ & $111.99 \pm 0.19$ & $22.82 \pm 0.82$ & - & - \\
P. glauca & AE & 2.2 & $59.88 \pm 0.02$ & - & - & - & - \\
& ME & 3.3 & $11.31 \pm 0.38$ & - & - & - & - \\
P. furfuracea & AE & 3.7 & $115.98 \pm 0.29$ & - & - & - & - \\
& ME & 8.2 & $3.03 \pm 0.02$ & - & - & - & - \\
R. fastigiata & AE & 1.4 & - & $112.9 \pm 0.92$ & $65.24 \pm 0.02$ & - & - \\
& ME & 4 & - & $41.5 \pm 0.00$ & $57.76 \pm 1.00$ & - & - \\
R. farinacea & AE & 3 & - & - & $57.61 \pm 0.14$ & - & - \\
& ME & 4.8 & - & - & $38.02 \pm 0.07$ & - & - \\
\hline
\end{tabular}

Data are presented as mean lichen acid amount \pm standard error (SE). AE: acetone; ME: methanol



Fig. 1. Chromatogram of standards used for identification. Retention times: 1. stictic acid-3.47 min; 2. fumarprotocetraric acid-5.42 min; 3. evernic acid-6.77 min; 4. usnic acid-13.70 min; and 5. atranorin-14.87 min 

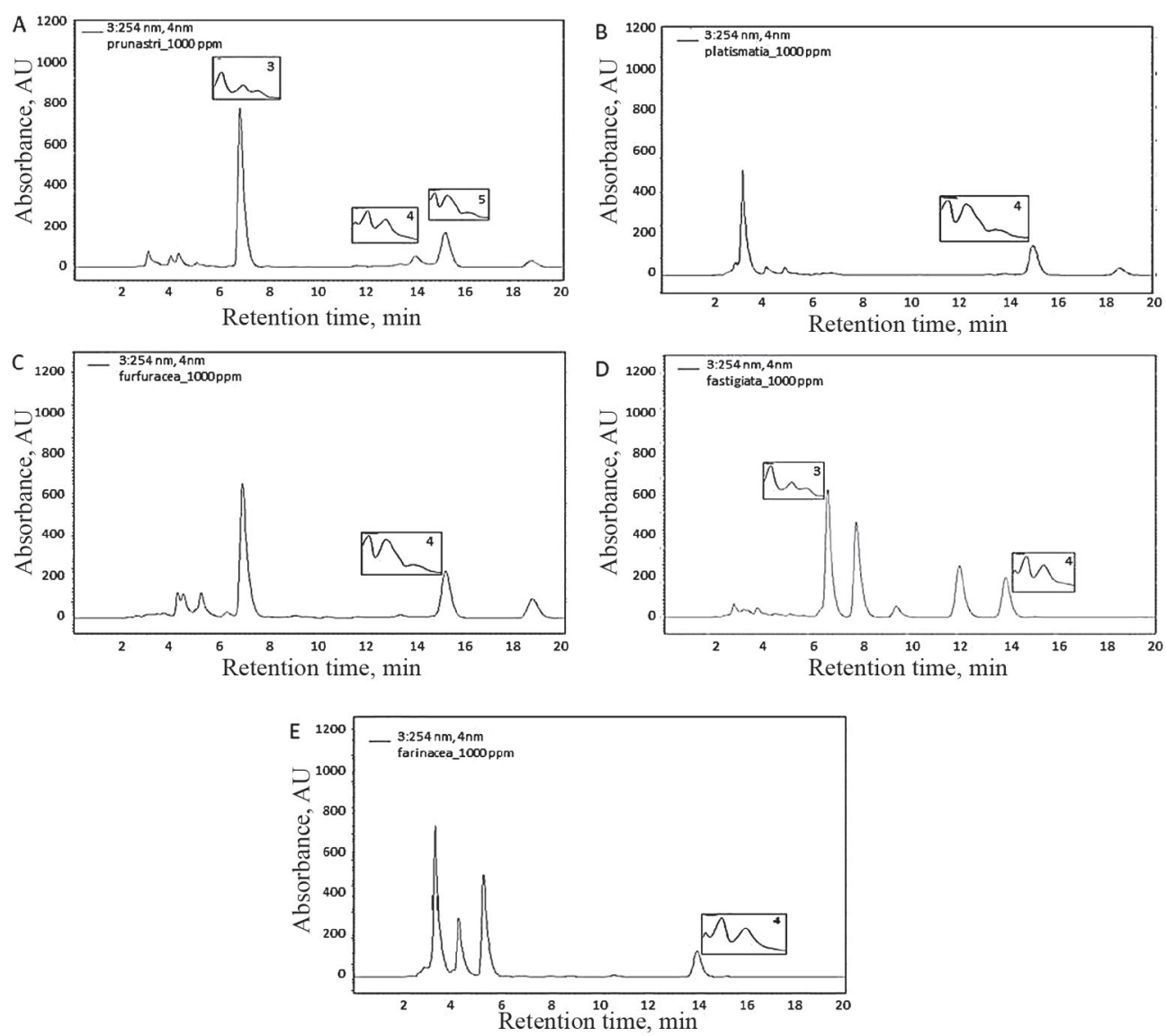

Fig. 2. HPLC chromatograms acquired at $254 \mathrm{~nm}$ of the acetone extract of tested lichen species. (A) E. prunastri,

(B) P. glauca, (C) P. furfuracea, (D) R. fastigiata, and (E) R. farinacea

In consistence with the previous study (KoSANIC et al., 2013), evernic acid was the main compound in acetone extract of E. prunastri. Only atranorin was detected in the acetone extract of $P$. glauca in our study. $P$. glauca showed higher atranorin concentration compared to $2.62 \mathrm{mg} \mathrm{g}^{-1}$ of atranorin in the study of NYBAKKEN and co-workers (2010). Moreover, acetone extract of $P$. furfuracea had the highest atranorin amount (Table 1). Similar to the result of KosANIC and co-workers (2013), the main compound of acetone extract of $P$. furfuracea was atranorin. Evernic acid and usnic acid were found in the acetone extract of $R$. fastigiata (Table 1). It was the second best evernic acid source after E. prunastri. Consistently with the report of RISTIC and co-workers (2016), $R$. fastigiata contained the most considerable usnic acid amount. We similarly reported that $R$. farinacea was a source of usnic acid (TAY et al., 2004). Previous studies showed that evernic acid, atranorin, and usnic acid had antimicrobial, antioxidant, anti-inflammatory, and anticancer activities (ODABASOGLU et al., 2006; TurK et al., 2006; MolnÁr \& FARKAS, 2010; KosAniC et al., 2014; Zhou et al., 2017).

Antiproliferative effects of acetone extracts were evaluated by MTT assay against MCF-7 (human breast cancer) and HepG2/C3A (human hepatocellular carcinoma) cell lines. HepG2/ 
C3A cell line was more vulnerable to lichen extracts. The highest effect was observed for $P$. glauca, followed by $R$. farinacea against HepG2/C3A cell line. The only lichen species that was active against both cell lines was $P$. furfuracea (Table 2).

Until now, few researches have evaluated the cytotoxic properties of selected lichen species. Secondary metabolites of $P$. furfuracea, olivetoric acid and pysodic acid, showed cytotoxicity against glioblastoma cell line U87MG (EMSEN et al., 2016). Anticancer activity of E. prunastri and P. furfuracea was determined against human melanoma (FemX) and colon carcinoma cell (LS174) (KosANIC et al., 2013). Acetone extract from $R$. fastigiata exhibited potent anticancer activity against Hela, A549 and LS174 cell lines (RISTIC et al., 2016). In one study, $n$-hexane, diethylether, and methanol extracts of E. prunastri and P. glauca demonstrated antiproliferative activity against MCF-7 cell line (BÉZIVIN et al., 2003). However, to our knowledge, acetone extracts of the tested lichens in our study have not been previously evaluated against MCF-7 and HepG2/C3A cell lines.

Methanolic extracts of lichens were evaluated for antioxidant potencies. Although a weak antioxidant activity has been reported for $P$. furfuracea (ODABASOGLU et al., 2004; KosANIC et al., 2013), high potency of $P$. furfuracea was observed in our study (Table 2). Methanol and acetone extracts of lichens were assessed for total phenol and flavonoid contents (Table 3). Generally, acetone extracts had higher total phenol and flavonoid contents than methanol extracts. Acetone extracts of E. prunastri and P. furfuracea had the highest phenolic contents, while acetone extracts of $R$. fastigiata and $R$. farinaceae possessed the highest flavonoid contents (Table 3). While Mitrovic and co-workers (2011) showed that $E$. prunastri had low total phenol and flavonoid contents $\left(80.73\right.$ and $27.46 \mathrm{mg} \mathrm{g}^{-1}$ dried extracts, respectively), our results exhibited higher amounts of phenolic and flavonoid capacities for E. prunastri. Consistent to the study of Mitrovic and co-workers (2014), total phenolic contents of $P$. glauca and $P$. furfuracea ranged from 39.75 to 63.69 and 123.09 to $131.92 \mathrm{mg}$ GAE/g dry weight, respectively. On the other hand, in the same study, $P$. glauca and $P$. furfuraceae showed around 6 and 3 fold lower antioxidant value than our result, respectively (DPPH, $\mathrm{IC}_{50}: 656.98$ and $95.33 \mu \mathrm{g} \mathrm{ml}^{-1}$, respectively). Moreover, RisTIC and co-workers (2016) showed low DPPH scavenging activity $\left(\mathrm{IC}_{50}: 423.51 \mu \mathrm{g} \mathrm{ml}^{-1}\right)$ and phenolic contents (33.49 $\mathrm{mg} \mathrm{g}^{-1}$ of dried extract) for $R$. fastigiata, but higher phenolic content and stronger DPPH radical scavenging activity were exhibited in our study (Table 2 and 3 ).

Table 2. Antiproliferative and antioxidant (DPPH) activities of tested lichen species

\begin{tabular}{|c|c|c|c|}
\hline \multirow[t]{4}{*}{ Lichen species } & \multicolumn{3}{|c|}{$\mathrm{IC}_{50}\left(\mu \mathrm{g} \mathrm{ml}^{-1}\right)$} \\
\hline & \multirow{2}{*}{\multicolumn{2}{|c|}{$\begin{array}{l}\text { Antiproliferative activity } \\
\text { Cell lines }\end{array}$}} & \multirow[t]{3}{*}{ Antioxidant activity } \\
\hline & & & \\
\hline & MCF-7 & HepG2/C3A & \\
\hline E. prunastri & $>200$ & $>200$ & 398.2 \\
\hline P. glauca & $>200$ & $111.7 \pm 1.7$ & 226.4 \\
\hline P. furfuracea & $146.5 \pm 2.8$ & $184.3 \pm 0.4$ & 28.3 \\
\hline R. fastigiata & $>200$ & $167.8 \pm 0.0$ & 111.1 \\
\hline R. farinacea & $>200$ & $>200$ & 486.1 \\
\hline
\end{tabular}

Data are presented as mean \pm standard error (SE). IC50: half maximal inhibitory concentration 
Table 3. Total phenol and flavonoid contents of tested lichen species

\begin{tabular}{lccc}
\hline Lichen species & Extract & Total phenolics mg GAE/g dried mass & Total flavonoids mg CE/g dried mass \\
\hline E. prunastri & AE & $213.4 \pm 0.01$ & $140.4 \pm 0.00$ \\
& ME & $153.1 \pm 0.00$ & $88.5 \pm 0.00$ \\
P. glauca & AE & $43.1 \pm 0.01$ & $81.6 \pm 0.00$ \\
P. furfuracea & AE & $47.2 \pm 0.00$ & $106.9 \pm 0.00$ \\
& ME & $186.4 \pm 0.00$ & $71.6 \pm 0.00$ \\
R. fastigiata & AE & $97.4 \pm 0.00$ & $104.0 \pm 0.00$ \\
& ME & $134.2 \pm 0.00$ & $373.8 \pm 0.00$ \\
& AE & $39.4 \pm 0.00$ & $94.8 \pm 0.00$ \\
& ME & $95.7 \pm 0.01$ & $189.3 \pm 0.00$ \\
\end{tabular}

Data are presented as mean \pm standard error (SE). AE: acetone; ME: methanol; GAE: gallic acid equivalent; CE: catechol equivalent

Zones of inhibition of bacterial growth by tested lichen species are reported in Table 4. Mostly, methanol extracts of tested lichen species exhibited higher antibacterial activity than acetone extracts. All lichen extracts were found to be active against Gram-positive bacteria ( $S$ auerus, $S$. epidermidis, and $S$. pyogenes). None of the tested lichen extracts showed antibacterial activity against $S$. typhimurium, . aeruginosa, and E. coli (data not shown).

Among the tested lichen species, the methanol extract of $R$. fastigiata showed the best antibacterial activity with inhibition against 6 out of 7 bacteria. Preceding studies (CANSARAN et al., 2007; ŞAHIN et al., 2015; RisTIC et al., 2016) reported that acetone extract of $R$. fastigiata showed effect against $E$. coli and $S$. aureus. Here, the antibacterial activity of $R$. fastigiata against $S$. epidermidis, S. pyogenes, $P$. vulgaris, $K$. pneumonia, and E. cloacae was investigated for the first time. Both acetone and methanol extracts of $P$. furfuracea showed strong activity against Gram-positive bacteria. Former studies reported that $P$. furfuracea exhibited antibacterial activity against E. coli, K. pneumonia, S. aureus, and P. vulgaris (TURK et al., 2006; GüVENÇ et al., 2012; KosANIC et al., 2013). However, inhibition of S. epidermidis and $S$. pyogenes by $P$. furfuracea was reported for the first time in our study. It was reported that $R$. farinacea demonstrated inhibition effect against $S$. aureus, $S$. epidermidis, E. coli, and P. vulgaris (TAY et al., 2004; KARAGÖZ et al., 2009; ŞAHIN et al., 2015). The methanol extract of E. prunastri was more effective than acetone extract. However, ASLAN and co-workers (2006) demonstrated weak antibacterial activity for methanol extract of E. prunastri. The acetone extract of $P$. glauca was found to be more active than methanol extracts against all Gram-positive bacteria. Mitrovic and co-workers (2014) showed that it was active against $S$. aureus, $P$. aureginosa, E. coli, and $S$. typhimurium, while we demonstrated the antibacterial activity of $P$. glauca against Gram-positive $S$. aureus. The inhibitory activity of $P$. glauca against $S$. epidermidis and $S$. pyogenes was examined for the first time in this study. 


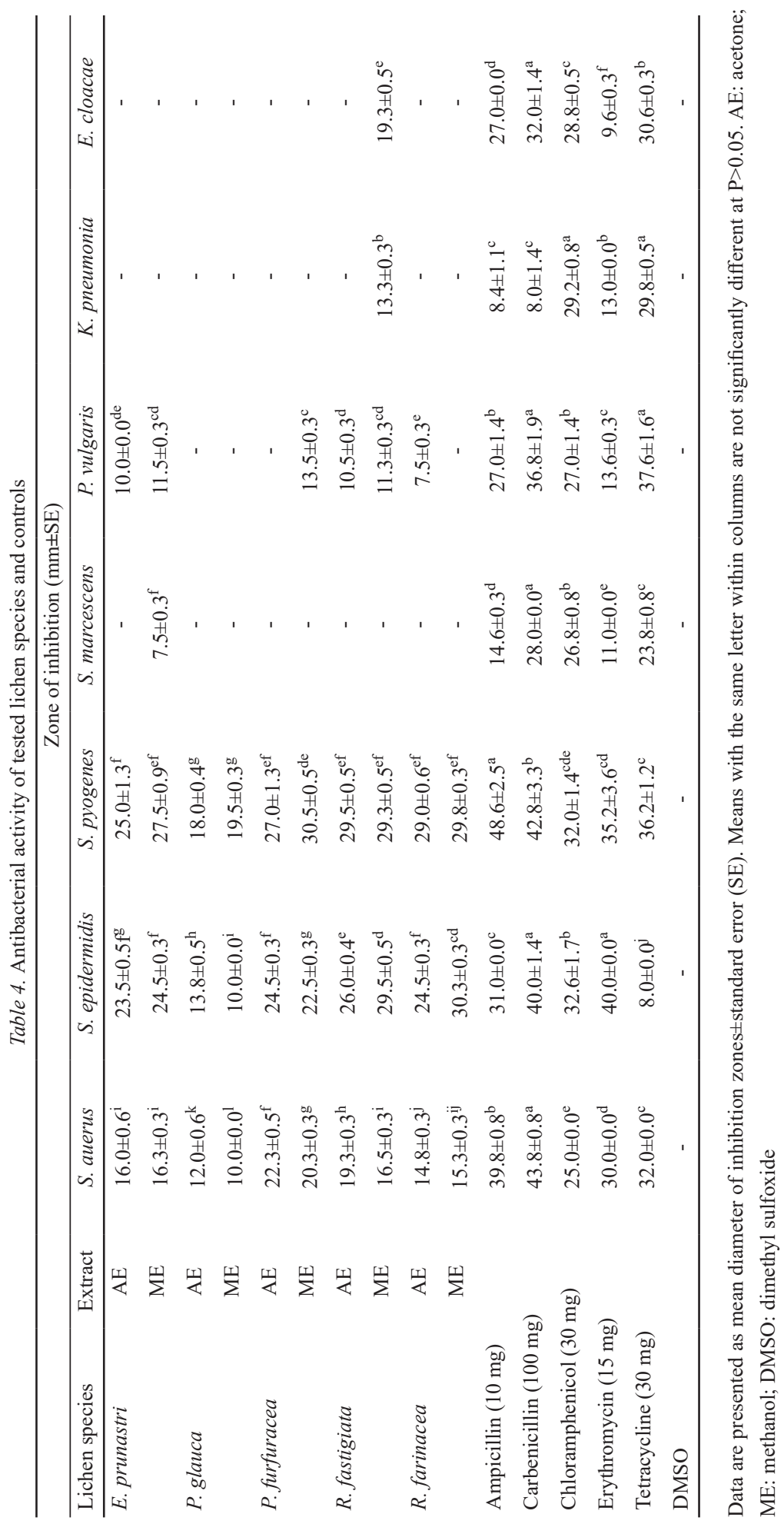




\section{Conclusions}

The current study reported the following findings for the first time: 1) quantitative analysis of atranorin, evernic acid, and usnic acid in tested lichen species growing in Turkey; 2) antiproliferative activity of acetone extract of $P$. glauca followed by $R$. farinacea against HepG2/C3A cell line, and also activity of $P$. furfuracea against both HepG2/C3A and MCF-7 cell line; 3 ) the potent DPPH radical scavenging activity of $P$. furfuracea and high phenolic contents of acetone extracts of $E$. prunastri and $P$. furfuracea; 4) antibacterial activity of $P$. glauca, P. furfuracea, and R. fastigiata against $S$. epidermidis and $S$. pyogenes, and also antibacterial activity of $R$. fastigiata against $P$. vulgaris, $K$. pneumonia, and E. cloacae. Taken together, further research is required to elucidate the mechanism of action of bioactive secondary metabolites detected in lichen species. The results of our study provide promising guideline regarding the potential uses of tested lichen species as a source of anticancer, antioxidant, and antibacterial agents.

Financial support was provided by Bolu Abant Izzet Baysal University, Scientific Research Projects (AIBU-BAP 2014.03.01.702 and OBAP 2013.03.01.591). We are grateful to Dr. Hakan Turker for his technical support.

\section{Conflict of interest}

The authors declare that they have no conflicts of interest.

\section{References}

ANDrews, J.M. (2009): BSAC standardized disc susceptibility testing method (version 8). J. Antimicrob. Chemoth., $64,454-489$.

Aslan, A., Güllüce, M., Sökmen, M., Adigüzel, A., Sahin, F. \& ÖzKan, H. (2006): Antioxidant and antimicrobial properties of the lichens Cladonia foliacea, Dermatocarpon miniatum, Everinia divaricata, Evernia prunastri, and Neofuscella pulla. Pharm. Biol., 44, 247-252.

Bézivin, C., Tomasi, S., LohÉzic-Le Dévéhat, F. \& Boustie, J. (2003): Cytotoxic activity of some lichen extracts on murine and human cancer cell lines. Phytomedicine, 10, 499-503.

BLoIs, M.S. (1958): Antioxidant determinations by the use of a stable free radical. Nature, 181, 1199.

Cansaran, D., Atakol, O., Halici, M.G. \& Aksoy, A. (2007): HPLC analysis of usnic acid in some Ramalina species from Anatolia and investigation of their antimicrobial activities. Pharm. Biol., 45, 77-81.

CHAPMAN, A.D. (2009): Numbers of living species in Australia and the world. Australian Biological Resources Study (ABRS), Canberra, Australia. p. 53.

Emsen, B., Aslan, A., Togar, B. \& Turkez, H. (2016): In vitro antitumor activities of the lichen compounds olivetoric, physodic and psoromic acid in rat neuron and glioblastoma cells. Pharm. Biol. 54, 1748-1762.

Güvenç, A., Akkol, E.K., Süntar, I., Keleş, H., Yildiz, S. \& ÇAlış, I. (2012): Biological activities of Pseudevernia furfuracea (L.) Zopf extracts and isolation of the active compounds. J. Ethnopharmacol., 144, 726-734.

Karagöz, A., Doruöz, N., Zeybek, Z. \& Aslan, A. (2009): Antibacterial activity of some lichen extracts. J. Med. Plants Res., 3, 1034-1039.

Korkmaz, A.I., Akgul, H., Sevindik, M., \& Selamoglu, Z. (2018): Study on determination of bioactive potentials of certain lichens. Acta Alimentaria, 47, 80-87.

Kosanic, M., Manojlović, N., Janković, S., Stanojković, T. \& Ranković, B. (2013): Evernia prunastri and Pseudoevernia furfuraceae lichens and their major metabolites as antioxidant, antimicrobial and anticancer agents. Food Chem. Toxicol., 53, 112-118.

Kosanic, M., Rankovic, B., Stanojkovic, T., Vasiljevic, P. \& Manojlovic, N. (2014): Biological activities and chemical composition of lichens from Serbia. EXCLIJ., 13, 1226-1238. 
Mitrovic, T., Stamenkovic, S., Cvetkovic, V., Radulovic, N., Mladenovic, M. ... \& Comic, L. (2014): Platismatia glaucia and Pseudevernia furfuracea lichens as sources of antioxidant, antimicrobial and antibiofilm agents. EXCLI J., 13, 938-953.

Mitrović, T., Stamenković, S., Cvetković, V., Tošić, S., Stanković, M., ... \& Markovic, S. (2011): Antioxidant, antimicrobial and antiproliferative activities of five lichen species. Int. J. Mol. Sci., 12, 5428-5448.

Molnár, K. \& Farkas, E. (2010): Current results on biological activities of lichen secondary metabolites: a review. Z. Naturforsch. C., 65, 157-173.

Mosmann, T. (1983): Rapid colorimetric assay for cellular growth and survival: Application to proliferation and cytotoxicity assays. J. Immunol. Methods, 65, 55-63.

Nybakken, L., Helmersen, A.M., GauslaA, Y. \& SelÅs, V. (2010): Lichen compounds restrain lichen feeding by Bank Voles (Myodes glareolus). J. Chem. Ecol. 36, 298-304.

Odabasoglu, F., Aslan, A., Cakir, A., Suleyman, H., Karagoz, Y., Halici, M. \& Bayir, Y. (2004): Comparison of antioxidant activity and phenolic content of three lichen species. Phytother. Res., 18, 938-941.

Odabasoglu, F., Cakir, A., Suleyman, H., Aslan, A., Bayir, Y., Halici, M. \& Kazaz, C. (2006): Gastroprotective and antioxidant effects of usnic acid on indomethacin-induced gastric ulcer in rats. J. Ethnopharmacol., 103, 59-65.

Ristic, S., Rankovic, B., Kosanic, M., Stamenkovic, S., Stanojković, T., Sovrlić, M. \& Manojlović, N. (2016): Biopharmaceutical potential of two Ramalina lichens and their metabolites. Curr. Pharm. Biotechnol., 17, $651-658$.

ŞAHIN, S., ORAN, S., ŞAHINTÜRK, P., DEMIR, C. \& ÖZTÜRK, Ş. (2015): Ramalina lichens and their major metabolites as possible natural antioxidant and antimicrobial agents. J. Food Biochem., 39, 471-477.

Sipman, H.J. \& Aptroot, A. (2001): Where are the missing lichens? Mycol. Res., 105, 1433-1439.

SlinKard, K. \& Singleton, V.L. (1977): Total phenol analysis: Automation and comparison with manual methods. Am. J. Enol. Vitic., 28, 49-55.

Tas, I., Yildirim, A.B., Ozyigitoglu, G.C., Yavuz, M.Z. \& Turker, A.U. (2017): Determination of biological activities (antibacterial, antioxidant and antiproliferative) and metabolite analysis of some lichen species from Turkey. Eur. J. Biomed. Pharm. Sci. (EJBPS), 4, 13-20.

TAY, T., TÜRK, A.Ö., YILmaz, M., Türk, H. \& KIVANÇ, M. (2004): Evaluation of the antimicrobial activity of the acetone extract of the lichen Ramalina farinacea and its $(+)$-usnic acid, norstictic acid, and protocetraric acid constituents. Z. Naturforsch. C., 59, 384-388.

Turk, H., Yilmaz, M., TaY, T., Turk, A.O. \& Kivanc, M. (2006): Antimicrobial activity of extracts of chemical races of the lichen Pseudevernia furfuracea and their physodic acid, chloroatranorin, atranorin, and olivetoric acid constituents. Z. Naturforsch. C., 61, 499-507.

Zhishen, J., Mengcheng, T. \& Jianming, W. (1999): The determination of flavonoid contents in mulberry and their scavenging effects on superoxide radicals. Food Chem., 64, 555-559.

Zhou, R., Yang, Y., Park, S.Y., Nguyen, T.T., Seo, Y.W., ... \& Kim, H. (2017): The lichen secondary metabolite atranorin suppresses lung cancer cell motility and tumorigenesis. Sci. Rep., 7, 8136. 